\title{
THE EFFECT OF PLANTING DENSITY AND NUMBER OF HAND WEEDING TIMES ON WEEDS CONTROL AND RELATIONSHIP BETWEEN MORPHOLOGICAL CHARACTERISTICS WITH CONTENT AND YIELD OF ESSENTIAL OIL OF SATUREJA HORTENSIS L.
}

\author{
Abdolmalek Karimi ${ }^{1}$, Ebrahim Gholamalipour Alamdari ${ }^{1}$, \\ Zinab Avarseji ${ }^{1}$, Ali Nakhzari Moghaddam ${ }^{1}$

\footnotetext{
${ }^{1}$ Department of Plant Production, Faculty of Agriculture and Natural Resources, Gonbad Kavous University, Gonbad Kavous, Golestan Province, Iran
} \\ Link to this article: https://doi.org/10.11118/actaun.2021.039 \\ Received: 5. 9. 2020, Accepted: 3. 6. 2021 \\ To cite this article: KARIMI ABDOLMALEK, ALAMDARI EBRAHIM GHOLAMALIPOUR, AVARSEJI ZINAB, \\ MOGHADDAM ALI NAKHZARI. 2021. The Effect of Planting Density and Number of Hand Weeding Times on \\ Weeds Control and Relationship Between Morphological Characteristics With Content and Yield of Essential Oil of \\ Satureja Hortensis L. Acta Universitatis Agriculturae et Silviculturae Mendelianae Brunensis, 69(3): 417-426.
}

\begin{abstract}
The aim of this study was to evaluate the effect of planting density and number of weeding times on weeds control and the relationship between morphological characteristics with the content and yield of Satureja hortensis essential oil (EO). S. hortensis planting density at four levels (50, 75, 100 and 125 plants per $\mathrm{m}^{2}$ ) was the first factor and hand weeding in 4 times (2, 4, 6 and 8 weeks after planting- WAP), 3 times (2, 4 and 8 WAP), 2 times ( 4 and 8 WAP) and weedy check as second factor. Dominant weeds were included redroot pigweed (Amaranthus retroflex L.), black nightshade (Solanum nigrum L.) and lambsquarters (Chenopodium album L.) in this field. Increasing Satureja hortensis density under densities of 50, 75 and 100 plants per $\mathrm{m}^{2}$ with weeding especially four times, significantly increased the dry weight and content of EO and yield of this plant. But the delay in the weeding times, such as twice weeding, significantly reduced this trait. This indicates that weeding in S. hortensis should be done at the beginning of the growing season due to its slow growth. Also, increasing the density of $S$. hortensis from 100 to 125 plants per $\mathrm{m}^{2}$ intensifies competition, so that its EO yield content decreased despite increasing the number of weeding times compared to the weedy check. Overall, due to the favorable effect of weed control under three or four weeding times on dry weight and content and EO yield of S. hortensis, weeding at the mentioned times is recommended in Gonbad Kavous area and areas with similar conditions to Gonbad Kavous.
\end{abstract}

Keywords: Satureja hortensis, planting density, hand weeding times, morphological characteristics, weeds control, content and yield of essential oil

\section{INTRODUCTION}

Weeds are one of the most important problems in organic farming. The costs of weed control in organic farming are so high that synthetic herbicides uses are prohibited as compared with permitted herbicides in conventional agriculture
(Abouziena et al., 2016). Weeds have a detrimental effect on medicinal plant production. The presence of weeds in the field of medicinal plant reduces the yield by 25 to $95 \%$ depending on the growing condition, content and quality of active metabolites in plants (Carrubba and Militello, 2013). 
There are some safe methods that can be used in organic farming of medicinal plants to control weeds, such as soil solarization, mulching, natural herbicides, warm water, and agronomic practices that have been successfully adopted in many countries as safe methods (Abouziena et al., 2016).

The critical period of weed interference (CPWI) can be defined as the stage in the growth cycle of any crop during which weeds must be controlled to prevent unrecoverable yield losses. CPWI knowledge also contributes to minimize yield losses that this crop can exhibit due to weed infestation (Safdar et al., 2016); determining CPWI is an indispensable tool for suggestion effective weed management strategies in any crop production system (Tursun et al., 2016).

The intensity and duration of weed interference are factors that determine the extent of yield losses (Swanton et al., 2015). Several studies (Kumar et al., 2015; Tursun et al., 2015; Yadav et al., 2018) reported that weed interference outside the critical period of weed control had a negligible effect on crop yield. Hence, determination of this critical period is essential for better weed management. In fact, it is the first step in an integrated weed management (IWM) strategies. Therefore, it helps to decide on weeds control at the right time, efficient use of herbicide and higher productivity (Kumar et al., 2015; Yadav et al., 2018). However, weed interference not only affects crop yield but also this causes change in content of secondary metabolites in plants, which accomplish important functions within the plants (Olivoto et al., 2017).

The first and most important step in weed management is to identify the species and understanding their distribution, so that they can be managed with an open vision and careful planning (Pourheidar Ghafarbi and Hassennszhad, 2013). It has been reported that any increase in crop density up to a certain range will result in a competition for crop yield (Giti et al., 2013). Several studies have shown that increasing weed suppression by decreasing crop row distance or increasing crop density can also be higher in a more uniform pattern even without weed pressure. Narrower rows to suppress wheat weeds (Drews et al., 2009) and rice has been reported (Chauhan and Johnson, 2011).

Satureja is a genus of aromatic plants belonging to Lamiaceae family. Satureja hortensis L. represents an annual herbaceous crop species, strongly branched with linear leaves. The flowers are also bisexual in purple or violet white with a red peeled on the inside grouped at the upper nodes of the branches (Bojor, 2003). The leaf, on the surface, has small spots called tubers with essential oils.

Identifying the dominant weeds in the cultivation of medicinal plants will be useful for growers. Therefore, due to the side effect of synthetic herbicides on the effective materials, optimal agronomic practices of plants can be a good option for controlling weeds. Far too little attention has so far been paid to study the effect of planting density and hand weeding times to control weed populations in medicinal plant of $S$. hortensis; however, such studies are essential to determine optimal planting density and weeds control in this plant. Therefore, the main objective of this study was to determine the effect of plant density and different number of hand weeding times on weeds control and the relationship between morphological characteristics with content and EO yield of S. hortensis.

\section{MATERIALS AND METHODS}

The field experiment was carried out in Shahabi Agriculture and Animal Husbandry complex located at Gonbad Kavous road to Dashliboron in Golestan province, Iran with a longitude 55 9' 30" and a latitude of $37^{\circ} 23^{\prime} 36^{\prime \prime}$ east, $50 \mathrm{~m}$ above sea level and with an average long-term annual rainfall of $300 \mathrm{~mm}$ in growing season 2018-2019.

The soil physical and chemical properties of the studied place was measured before doing the experiment. In so doing, six points of soil sample at a depth of 0 to $30 \mathrm{~cm}$ were randomly collected by auger each point of which contained approximately $3 \mathrm{~kg}$ of soil. The soil of six points was then mixed with each other well. Finally, a mixture of $4 \mathrm{~kg}$ of soil was prepared and transferred to Gonbad Kavous Soil Laboratory for physical and chemical analysis. Chemical properties of the topsoil layer of the experimental place were: $\mathrm{pH}$ (7.38), electrical conductivity $\left(7.8 \mathrm{~mm} \mathrm{~cm}^{-1}\right)$, organic carbon $(0.35 \%)$, total nitrogen (0.04\%), soluble phosphorus (6 ppm) and soluble potassium (474 ppm). The soil texture containing 15, 24 and 64\% clay, sand and silt was loamy silt respectively. The size of the plots was $4 \times 5 \mathrm{~m}$ and the distance between the plots was one meter.

This experiment was performed as a factorial experiment base on the randomized complete block design in three replications. Planting density of S. hortensis at four levels (50, 75, 100 and 125 plants per $\mathrm{m}^{2}$ ) was the first factor and hand weeding in 4 times (2, 4, 6 and 8 weeks after planting- WAP), 3 times of weeding (2, 4 and 8 WAP), 2 times of weeding ( 4 and 8 WAP) and weedy check in during the growing season as second factor.

First, the land was selected and then non-plant remains such as rocks, metal and plastic parts were removed. Plowing was firstly done to prepare the seedbed in relatively deep manner with the help of a reversible plow in March and April 2019. Additional operations such as crushing the mulch, softening the soil and leveling the ground were then performed using a disc and a trowel.

$100 \mathrm{~kg} / \mathrm{ha}$ Urea $(46 \% \mathrm{~N})$ and $100 \mathrm{~kg} / \mathrm{ha}$ Triple Super Phosphate $\left(46 \% \mathrm{P}_{2} \mathrm{O}_{5}\right)$ were used as fertilizer source for nitrogen and phosphorus respectively. The entire rate of basic fertilizer of phosphorus and half of nitrogen fertilizers were applied when planting was simultaneously done with secondary 
plowing at a depth of $10 \mathrm{~cm}$. The remaining half of nitrogen was applied at the time of flowering as a top dressing. Potash fertilizer was not used due to the richness of the soil.

Certified seeds of $S$. hortensis were obtained from Pakan Bazr Isfahan Company, located Iran. S. hortensis seeds were planted by hand on April 4, 2019. The distance between planting rows and planting depth of $S$. hortensis seeds were 30 and $5 \mathrm{~cm}$, respectively. After seedlings growth, additional seedlings was removed to create the desired density according to the design plan.

\section{Measurement of Density and Dry Weight of Weeds}

To evaluate weed density, three $0.5 \times 0.5 \mathrm{~m}$ quadrats were encompassed, and the weeds were identified and counted separately based on genus and specie. Then, the average plant density of each weed and their total in terms of number per $\mathrm{m}^{2}$ was reported. To measure the dry weight of each weed, after separating the species of each weed in each quadrate, they were removed from the soil surface. Then, they were half withered in indirect sunlight and finally dried with the help of oven at $60{ }^{\circ} \mathrm{C}$ until a constant weight is reached $(10 \%$ on the base weight (Caceres, 2000)) (Martinov et al., 2007). Then it was weighed with a digital lab scale (BEST Company, Model of MT-200) with an accuracy of $0.01 \mathrm{~g}$ and the average of three quadrats per plot was reported.

\section{Measurement of $S$. Hortensis Characteristics}

Plant height at the beginning of S. hortensis flowering stage was measured in each experimental plot. For this purpose, 10 plants from each experimental plot considering the marginal effect were randomly selected and their average was reported. To measure the fresh and dry weight of S. hortensis, they were removed from the soil surface. Then they were dried in an oven at $40^{\circ} \mathrm{C}$ until a constant weight is reached (To prevent the breakdown of allochemicals). It was then weighed with a digital lab scale (BEST Company, Model of MT-200) with an accuracy of $0.01 \mathrm{~g}$ and the average of three quadrats per plot was reported.

To measure leaf area, three $0.5 \times 0.5 \mathrm{~m}$ quadrats were encompassed in each plot randomly. At the densities of 50, 75, 100 and 125 plants per $\mathrm{m}^{2}$, all $S$. hortensis leaves were separated and the leaf area was then reported in the plant per $\mathrm{mm}^{2}$ by Leaf Area Meter (Delta-t model).

In order to evaluate content and yield of EO, S. hortensis aerial parts were harvested and dried in the oven at $40^{\circ} \mathrm{C}$ (to prevent the volatile allelochemicals of the EO). In so doing, A $20 \mathrm{~g}$ sample of $S$. hortensis aerial parts was first grounded into small pieces by a mill and then passed through sieves with 8 mesh (number of squares or sieve particles per inch). In the next step, $150 \mathrm{ml}$ of distilled water was added to it and placed in a $1000 \mathrm{ml}$ volumetric balloon on the heater for 2 hours. Due to heat and increasing water vapor pressure, the essential oil droplets became liquid in contact with the cold wall of the condenser (condensate action). Subsequently, most of the EO was placed at the end of the calibrated tube due to its lower density than that of water. The resulting EO was collected by syringe and then placed in micro vials. Sodium sulfate was used in order to extract water from the EO. The vials containing the EO were weighed by a digital scale with a 0.0001 accuracy and the EO content was calculated according to the following equation:

Content of essential oil (\%) =

$=\frac{\text { Essence weight }}{\text { Sample dry weight }} \times 100$.

Then the yield of S. hortensis EO (kg.ha-1) was obtained by multiplying the content of EO with the dry matter yield of experimental treatments.

The data normalization was tested by Minitab software (Version 14) to make the data normal. The data were then analyzed using SAS 9.3 version (SAS Institute, 2011) and mean data were compared using Least Significant Difference (LSD) test at 5\% probability level.

\section{RESULTS}

\section{Effect of Plant Density and Number of Weeding Times on Morphological Traits, Content and EO Yield of S. Hortensis}

Planting density and number of weeding times significantly affected the plant height, fresh and dry weight, leaf area, content and EO yield of $S$. hortensis at $\mathrm{p}<0.01$. Also, the interaction effects of planting density and number of weeding times on all measured traits except leaf area were significant at $\mathrm{p}<0.01$ (Tab. I).

\section{Plant Height}

The amount of changes in the plant height of S. hortensis was between 45.33 and $36.33 \mathrm{~cm}$. The highest plant height was obtained with the treatment of 125 plants per $\mathrm{m}^{2}$ in weedy check. However, no statistically significant difference was observed with the treatment of 100 plants per $\mathrm{m}^{2}$ in weedy check. Therefore, they were placed in the same group. But the lowest plant height was related to 75 plants per $\mathrm{m}^{2}$ with weeding three times, but the difference with some treatments was not significant (Tab. II).

\section{Fresh Weight}

Fresh weight of $S$. hortensis under different treatments of weeding times and densities except 125 plants per $\mathrm{m}^{2}$ was more than weedy check. The highest fresh weight was related to 75 plants per $\mathrm{m}^{2}$ with weeding 4 times in the amount of $8140 \mathrm{mg}$ per plant. The difference with 50 plants in the same number of hand weeding times was not significant. 
I: Analysis of variance (ANOVA) of the effect of planting density and number of weeding times on morphological traits, content and EO yield of S. hortensis

\begin{tabular}{lccccccc}
\hline S.O.V & Df & Plant height & $\begin{array}{c}\text { Plant fresh } \\
\text { weight }\end{array}$ & $\begin{array}{c}\text { Plant dry } \\
\text { weight }\end{array}$ & Leaf area & $\begin{array}{c}\text { Content } \\
\text { of essential oil }\end{array}$ & $\begin{array}{c}\text { Essential } \\
\text { oil yield }\end{array}$ \\
\hline $\mathrm{r}$ & 2 & $25.00^{\text {ns }}$ & $244508.33^{\text {ns }}$ & $10399.32^{\text {ns }}$ & $370208.30^{\text {ns }}$ & $0.004^{\text {ns }}$ & $3.45^{\text {ns }}$ \\
$\mathrm{a}$ & 3 & $1191.97^{* *}$ & $7790127.78^{* *}$ & $748520.06^{* *}$ & $44240763.90^{* *}$ & $1.25^{* *}$ & $171.95^{* *}$ \\
$\mathrm{~b}$ & 3 & $4024.31^{* *}$ & $10593294.44^{* *}$ & $469734.95^{* *}$ & $1269097.20^{* *}$ & $0.26^{* *}$ & $297.06^{* *}$ \\
$\mathrm{a} \times \mathrm{b}$ & 9 & $2200.23^{* *}$ & $3595496.30^{* *}$ & $158124.49^{* *}$ & $24282.40^{\text {ns }}$ & $0.39^{* *}$ & $67.59^{* *}$ \\
$\mathrm{e}$ & 30 & 169.44 & 188743.89 & 8010.62 & 146208.3 & 0.008 & 5.56 \\
\hline $\mathrm{CV}(\%)$ & & 3.29 & 8.25 & 8.58 & 5.42 & 3.49 & 8.83 \\
\hline
\end{tabular}

${ }^{* *}:$ indicate significant difference at 1\% probability level and ns: non-significant difference, r: replication, a: plant density, b: number of weeding times, e: error, CV: Coefficient Variance

II: Mean comparison of interaction effect of planting density and number of weeding times on morphological traits and content of EO yield of $S$. hortensis

\begin{tabular}{|c|c|c|c|c|c|c|}
\hline $\begin{array}{c}\text { Density } \\
\text { (plants per } \mathrm{m}^{2} \text { ) } \\
\end{array}$ & $\begin{array}{c}\text { Number } \\
\text { of hand weeding }\end{array}$ & $\begin{array}{l}\text { Plant height } \\
\left(\mathrm{mm}^{2}\right)\end{array}$ & $\begin{array}{c}\text { Fresh weight } \\
\text { (mg/plant) }\end{array}$ & $\begin{array}{l}\text { Dry weight } \\
\text { (mg/plant) }\end{array}$ & $\begin{array}{c}\text { Content of } \\
\text { essential oil (\%) }\end{array}$ & $\begin{array}{l}\text { Essential oil } \\
\text { yield (kg/ha) }\end{array}$ \\
\hline \multirow{4}{*}{50} & Weedy check & $370.00 \pm 10.00^{\mathrm{fg}}$ & $3663.30 \pm 320.05^{\mathrm{e}}$ & $732.67 \pm 64.01^{\mathrm{f}}$ & $2.03 \pm 0.03^{g}$ & $7.44 \pm 0.26^{g}$ \\
\hline & 2 times & $376.70 \pm 5.80^{\mathrm{fg}}$ & $5860.00 \pm 913.40^{b}$ & $1183.67 \pm 182.24^{\text {cd }}$ & $2.11 \pm 0.07 \mathrm{~g}$ & $12.49 \pm 0.34^{\mathrm{f}}$ \\
\hline & 3 times & $376.70 \pm 5.80^{\mathrm{fg}}$ & $6116.70 \pm 281.13^{b}$ & $1185.33 \pm 15.01^{c d}$ & $2.09 \pm 0.07 \mathrm{~g}$ & $12.39 \pm 0.67^{\mathrm{f}}$ \\
\hline & 4 times & $420.00 \pm 17.30^{\mathrm{bcd}}$ & $8060.00 \pm 850.70^{a}$ & $1645.33 \pm 219.15^{\mathrm{a}}$ & $2.77 \pm 0.07^{\text {cde }}$ & $22.79 \pm 0.93^{\mathrm{e}}$ \\
\hline \multirow{4}{*}{75} & Weedy check & $413.30 \pm 15.30^{\mathrm{cd}}$ & $3676.70 \pm 440.15 \mathrm{e}$ & $823.73 \pm 89.71^{\mathrm{ef}}$ & $2.02 \pm 0.08^{\mathrm{g}}$ & $12.48 \pm 0.34^{\mathrm{f}}$ \\
\hline & 2 times & $373.30 \pm 5.80^{\mathrm{fg}}$ & $6093.30 \pm 107.86^{b}$ & $1347.80 \pm 30.21^{b}$ & $2.17 \pm 0.08^{g}$ & $21.94 \pm 0.58^{e}$ \\
\hline & 3 times & $363.30 \pm 11.50^{g}$ & $5953.30 \pm 94.52^{\mathrm{b}}$ & $1304.53 \pm 13.77^{\mathrm{bc}}$ & $2.73 \pm 0.08^{e}$ & $26.71 \pm 0.31^{\mathrm{d}}$ \\
\hline & 4 times & $423.30 \pm 5.80^{\mathrm{bc}}$ & $8140.00 \pm 221.13^{\mathrm{a}}$ & $1786.13 \pm 31.57^{\mathrm{a}}$ & $2.98 \pm 0.12^{b}$ & $39.92 \pm 0.56^{\mathrm{a}}$ \\
\hline \multirow{4}{*}{100} & Weedy check & $440.00 \pm 10.00^{\mathrm{ab}}$ & $4223.30 \pm 136.50^{\text {cde }}$ & $766.53 \pm 25.14^{\mathrm{ef}}$ & $2.90 \pm 0.13^{\mathrm{bc}}$ & $22.23 \pm 0.27^{e}$ \\
\hline & 2 times & $400.00 \pm 20.00^{\mathrm{dc}}$ & $4843.30 \pm 219.62^{c}$ & $895.87 \pm 31.29^{c}$ & $2.88 \pm 0.10 \mathrm{~b}^{\text {cde }}$ & $25.80 \pm 0.77^{d}$ \\
\hline & 3 times & $373.30 \pm 11.50^{\mathrm{fg}}$ & $4453.30 \pm 560.03^{\mathrm{cd}}$ & $819.88 \pm 95.58^{e f}$ & $2.90 \pm 0.10^{\mathrm{bcd}}$ & $21.32 \pm 0.25^{e}$ \\
\hline & 4 times & $370.00 \pm 20.00^{\mathrm{fg}}$ & $5743.30 \pm 140.48^{\mathrm{b}}$ & $1068.35 \pm 28.42^{\mathrm{d}}$ & $2.89 \pm 0.02^{\mathrm{bcd}}$ & $30.88 \pm 0.64^{c}$ \\
\hline \multirow{4}{*}{125} & Weedy check & $453.30 \pm 15.30^{\mathrm{a}}$ & $4230.00 \pm 95.39^{\text {cde }}$ & $757.67 \pm 10.72^{\mathrm{ef}}$ & $3.19 \pm 0.14^{\mathrm{a}}$ & $30.21 \pm 0.35^{c}$ \\
\hline & 2 times & $413.30 \pm 15.30^{\text {cd }}$ & $4020.00 \pm 117.89^{\mathrm{de}}$ & $866.60 \pm 140.02^{\mathrm{ef}}$ & $3.23 \pm 0.06^{\mathrm{a}}$ & $34.99 \pm 0.99^{b}$ \\
\hline & 3 times & $376.70 \pm 15.30^{\mathrm{fg}}$ & $4376.70 \pm 261.02^{\text {cde }}$ & $780.40 \pm 52.14^{e f}$ & $2.75 \pm 0.09^{\mathrm{de}}$ & $26.83 \pm 0.37^{d}$ \\
\hline & 4 times & $386.70 \pm 11.50^{\mathrm{ef}}$ & $4813.30 \pm 762.65^{c}$ & $723.87 \pm 29.34^{\mathrm{f}}$ & $2.44 \pm 0.11^{\mathrm{f}}$ & $22.08 \pm 0.50^{\mathrm{e}}$ \\
\hline \multicolumn{2}{|c|}{ LSD5\% } & 21.10 & 729.19 & 150.24 & 0.15 & 3.88 \\
\hline
\end{tabular}

Different letters in each column represent significance at 5\% probability level based on least significant difference (LSD) test

Overall, the rate of increase in fresh weight of plants in densities of more than 75 plants per $\mathrm{m}^{2}$ due the increasing number of weeding was more than weedy check (Tab. II).

\section{Dry Weight}

The dry weight of S. hortensis at 50, 75 and 100 plant densities per $\mathrm{m}^{2}$ had a significant increasing trend with increasing number of weeding times compared to weedy check. The highest plant dry weight was related to 75 plant density with weeding four times $(1786 \mathrm{mg} /$ plant $)$ which did not show a statistically significant difference with 50 plant density in the same number of hand weeding times, Therefore, they were placed in the same group statistically. The number of weeding times also did not show a significant effect on dry weight per plant at a density of 125 plants per $\mathrm{m}^{2}$ compared to the weedy check and they had the least amount (Tab. II).

Dry weight was positively correlated with fresh weight $\left(r=+0.974^{* *}\right)$ and EO yield $\left(r=+0.831^{* *}\right)$. However, there were negative correlation with the leaf area $\left(r=-0.438^{* *}\right)$ and EO content EO $\left(\mathrm{r}=-0.523^{* *}\right)$ (Tab. III). 
III: Correlation of morphological traits, content and EO yield of S. hortensis

\begin{tabular}{|c|c|c|c|c|c|}
\hline Characteristics & Fresh weight & Dry weight & Leaf area & Content of essential oil & Essential oil yield \\
\hline Fresh weight & 1 & & & & \\
\hline Dry weight & $0.974^{* *}$ & 1 & & & \\
\hline Leaf area & $-0.356^{*}$ & $-0.438^{* *}$ & 1 & & \\
\hline Content of essential oil & $-0.478^{* *}$ & $-0.523^{* *}$ & $0.613^{* *}$ & 1 & \\
\hline Essential oil yield & $0.819^{* *}$ & $0.831^{* *}$ & $-0.204^{\text {ns }}$ & $0.011^{\text {ns }}$ & 1 \\
\hline
\end{tabular}

${ }^{* *}$ : indicate significant difference at $1 \%$ probability level and ns: non-significant difference

\section{Leaf Area}

Leaf area of S. hortensis increased with increasing plant density from 50 to 75 plants per $\mathrm{m}^{2}$. The leaf area at a density of 75 plants per $\mathrm{m}^{2}$ was equal to $9200 \mathrm{~mm}^{2}$. Increasing the number of plants from 100 to 125 per $^{2}$ led to intense competition and shading of plants, so that the leaf area showed a sharp decline compared to other densities (Fig. 1). Also, this characteristic increased with increasing number of weeding times, but the amount of this increase was less due to the intensification of plant competition (Fig. 2).

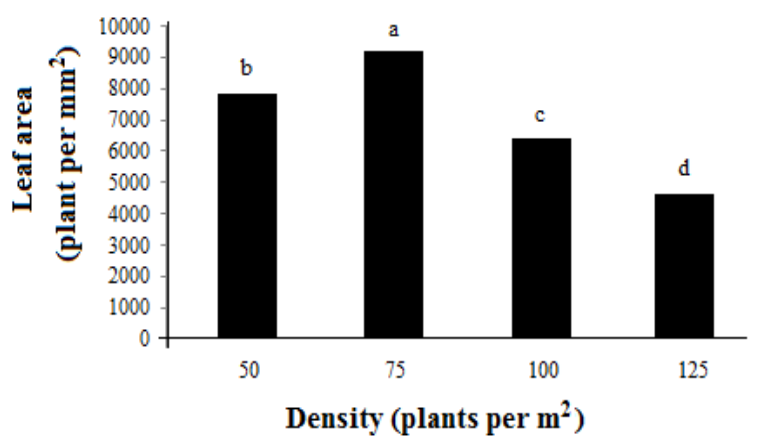

1: The effect of different planting densities on leaf area of S. hortensis

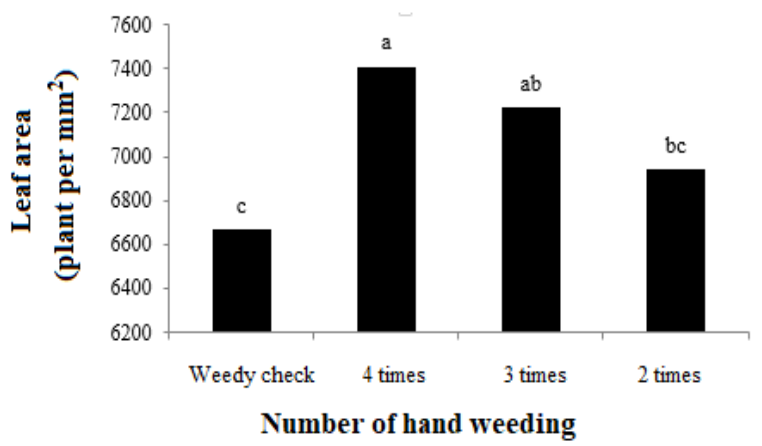

2: The effect of number of weeding times on the leaf area of S. hortensis

Leaf area was negatively correlated with fresh weight $\left(r=-0.356^{* *}\right)$ and dry weight $\left(r=-0.438^{* *}\right)$, but there were positive correlation with EO content $\left(\mathrm{r}=+0.613^{* *}\right)$ (Tab. III).

\section{EO Content}

EO content in density of 50 plants per $\mathrm{m}^{2}$ was significantly increased in four times of weeding (36.45\%) compared to weedy check. Also, this trait increased with an increase of planting density from 50 to 75 plants per $\mathrm{m}^{2}$ in comparison with weedy check. The highest value was related to weeding four times in the amount of 2.98\%. Increasing the number of plants per $\mathrm{m}^{2}$ from 75 to 100 and 125 plants intensified the plant competition for environmental potentials and then the EO content although the application of different weeding treatments increased significantly. The highest significant content of EO was thus obtained in density of 125 plants per $\mathrm{m}^{2}$ in weedy check treatment (3.19\%) and twice weeding (3.23\%) (Tab. II).

EO content was negatively correlated with fresh weight $\left(\mathrm{r}=-0.438^{* *}\right)$ and dry weight (weight $\left(\mathrm{r}=-0.523^{* *}\right)$ and there was positively correlated with leaf area $\left(r=+0.613^{* *}\right)$. Also, no significant correlation was observed between content and EO yield (Tab. III).

\section{EO Yield}

Increasing the number of weeding times in densities of 50 and 75 plants per $\mathrm{m}^{2}$ has increased the yield of $S$. hortensis EO. The highest EO yield was obtained in weeding four times $(39.92 \mathrm{~kg} / \mathrm{ha})$. The EO yield decreased with increasing density of $S$. hortensis despite of any increase in the content of EO compared to two densities of 50 and 75 plants per $\mathrm{m}^{2}$ (Tab. II).

\section{The Effect of Planting Density and Number of Weeding Times on Density and Dry Weight of Dominant Weeds in S. Hortensis}

The dominant weeds in the S. hortensis experimental field during the growing season included redroot pigweed (Amaranthus retroflex), black nightshade (Solanum nigrum) and lambsquarters (Chenopodium album). The effect of plant density, number of weeding times and their interaction on density and dry weight of $A$. retroflex weed was significant at $1 \%$ probability level. In contrast, the effect of these factors in different treatments were only significant on plant density S. nigrum at the level of $1 \%$ probability (Tab. IV). 
IV: Analysis of variance (ANOVA) of the planting density and number of weeding times on density and dry weight of each dominant weed and their total

\begin{tabular}{|c|c|c|c|c|c|c|c|c|c|}
\hline S.O.V & $\mathrm{df}$ & $\begin{array}{c}\text { Density } \\
\text { of } \\
\text { A. retroflexus }\end{array}$ & $\begin{array}{l}\text { Dry weight } \\
\text { of } \\
\text { A. retroflexus }\end{array}$ & $\begin{array}{l}\text { Density } \\
\text { of } \\
\text { S. nigrum }\end{array}$ & $\begin{array}{c}\text { Dry weight } \\
\text { of } \\
\text { S. nigrum }\end{array}$ & $\begin{array}{l}\text { Density } \\
\text { of } \\
\text { C. album }\end{array}$ & $\begin{array}{c}\text { Dry weight } \\
\text { of } \\
\text { C. album }\end{array}$ & $\begin{array}{c}\text { Total } \\
\text { density } \\
\text { of weeds }\end{array}$ & $\begin{array}{c}\text { Total } \\
\text { dry weight } \\
\text { of weeds }\end{array}$ \\
\hline $\mathrm{r}$ & 2 & $1.65^{\mathrm{ns}}$ & $0.35^{\mathrm{ns}}$ & $0.15^{\text {ns }}$ & $15.89^{\mathrm{ns}}$ & $0.08^{\text {ns }}$ & $0.003^{\mathrm{ns}}$ & $0.81^{\mathrm{ns}}$ & $4.22^{\mathrm{ns}}$ \\
\hline a & 3 & $117.47^{* *}$ & $106.95^{* *}$ & $29.41^{* *}$ & $2.70^{\mathrm{ns}}$ & $0.14^{\mathrm{ns}}$ & $0.21^{\mathrm{ns}}$ & $291.69^{* *}$ & $3731.36^{* *}$ \\
\hline b & 3 & $26591.58^{* *}$ & $23304.79^{* *}$ & $10436.30^{* *}$ & $9990.54^{* *}$ & $7.86^{* *}$ & $0.01^{\mathrm{ns}}$ & $75533.19^{* *}$ & $1314181.70^{* *}$ \\
\hline$a \times b$ & 9 & $74.68^{* *}$ & $80.01^{* *}$ & $21.11^{* *}$ & $1.69^{\text {ns }}$ & $0.06^{\mathrm{ns}}$ & $0.0004^{\text {ns }}$ & $182.82^{* *}$ & $112.30^{\text {ns }}$ \\
\hline E & 30 & 5.98 & 3.19 & 2.57 & 14.42 & 0.17 & 0.13 & 8.46 & 44.09 \\
\hline CV (\%) & & 7.59 & 7.05 & 9.37 & 24.56 & 28.46 & 30.41 & 5.61 & 3.57 \\
\hline
\end{tabular}

${ }^{* *}$ : indicate significant difference at 1\% probability level and ns: non-significant difference, r: replication, a: plant density, b: number of weeding times, e: error, CV: Coefficient Variance

\section{The Effect of Number of Weeding Times on Density of $C$. Album, Dry Weight of $S$. Nigrum and Total Dry Weight of Weeds}

\section{Density of C. Album}

The density of $C$. album significantly decreased under different weeding times compared to weedy check. Weeding two and three times with one plant per $\mathrm{m}^{2}$ had the lowest number. However, their difference with weeding four times were not significant (Tab. V).

\section{Dry Weight of S. Nigrum}

The range of changes in dry weight of $S$. nigrum was between 58.7 and 0.71 gram per $\mathrm{m}^{2}$. The highest amount of dry weight was related to weedy check treatment. In contrast, twice weeding had the lowest amount in terms of this trait, so that the difference with three and four weeding times was not statistically significant (Tab. V).

\section{Total Dry Weight of Weeds}

Total dry weight of the dominant weeds under different weeding times decreased with the same significant level (Tab. V).

\section{The Effect of $S$. Hortensis Densities on Total Dry Weight of Different Weed Species}

Total dry weight of weeds was decreased under densities of 100 and 125 plants per $\mathrm{m}^{2}$ as compared to 50 and 75 plants per $\mathrm{m}^{2}$ (Fig. 3).
The Effects of $S$. Hortensis Densities and Number of Weeding Times on Density and Dry Weight of $A$. Retroflexus and $S$. Nigrum Density

Density of dominant weed species such as $A$. retroflexus and $S$. nigrum decreased with any increase in the number of weeding times at certain densities of $S$. hortensis with a similar trend. A. retroflex with 113 plants per $\mathrm{m}^{2}$ had the highest value in weedy check. The highest total weed density also belonged to weedy check at a density of 50 plants per $\mathrm{m}^{2}$. However, the lowest total weed density was obtained at 125 plants per $\mathrm{m}^{2}$ (7.67) in weeding four times, which did not show a statistically significant difference with some weeding treatments at certain densities (Tab. VI).

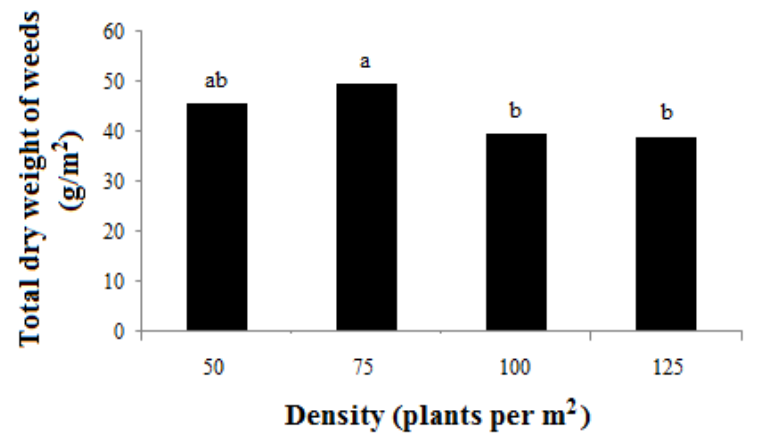

3: The effect of $S$. hortensis densities on total dry weight of weed species

V: The effect of number of weeding times on density of Chenopodium album, dry weight of Solanum nigrum and total dry weight of weeds

\begin{tabular}{cccc}
\hline $\begin{array}{c}\text { Characteristics/ } \\
\text { Number of hand weeding }\end{array}$ & $\begin{array}{c}\text { Density of } \text { C. album } \\
\left(\text { plants per } \mathrm{m}^{2}\right)\end{array}$ & $\begin{array}{c}\text { Dry weight of } \text {. nigrum } \\
\left(\mathrm{g} / \mathrm{m}^{2}\right)\end{array}$ & $\begin{array}{c}\text { Total dry weight of weeds } \\
\left(\mathrm{g} / \mathrm{m}^{2}\right)\end{array}$ \\
\hline Weedy check & $2.67 \mathrm{a}$ & $58.74 \mathrm{a}$ & $154.21 \mathrm{a}$ \\
\hline times & $1.17 \mathrm{~b}$ & $1.39 \mathrm{~b}$ & $7.80 \mathrm{~b}$ \\
3 times & $1.00 \mathrm{~b}$ & $1.003 \mathrm{~b}$ & $6.49 \mathrm{~b}$ \\
2 times & $1.00 \mathrm{~b}$ & $0.71 \mathrm{~b}$ & $4.98 \mathrm{~b}$ \\
\hline LSD 5\% & 0.35 & 3.17 & 6.45 \\
\hline
\end{tabular}

Different letters in each column represent significance at 5\% probability level based on least significant difference (LSD) test 


\section{The Effects of $S$. Hortensis Densities and Number of Weeding Times on Dry Weight of A. Retroflexus}

Increasing the plant density of $S$. hortensis at all levels of weeding times decreased the dry weight of the A. retroflexus compared to weedy check. On the other hand, with any increase in S. hortensis density, the density of $A$. retroflexus decreased. On the other hand, as the density of the A. retroflexus decreased, its dry weight also decreased (Tab. VI).

\section{DISCUSSION}

Plant height of $S$. hortensis increased with any increase in plant density. Also, dry weight of this plant increased up to 100 plants per $\mathrm{m}^{2}$ with weeding four times. Any increase in plant height under increasing planting density may be attributed to vigorous plant pressure with high competition for light, nutrients, and space in weed free environment. This result is in agreement with those of Al-Ramamneh (2009), Kizil et al. (2007) and Naghdi Badi et al. (2004). Raoufi et al. (2014), stated that weeds competition significantly reduced peppermint fresh weight. Also, a wide range of weeds observed in this field by shading on peppermint prevented the proper growth of this plant.
Increasing the density of S. hortensis from 50 plants upwards, provides a good relative weeds control which has intensified the competition in plants and weeds and thus increased EO content. However, the EO yield at 100 and 125 plants per $\mathrm{m}^{2}$ especially in fewer weeding times decreased. Mohammad Dust Chamanabad (2011) reported that weeds in the field using nutrients were more successful in competing with the main plant, thereby reducing the EO yield. Raoufi and Giti (2015) reported that treatments of weeding and density increased fresh and dry weight, green cover percentage and EO yield of peppermint. Hence, the maximum yield of the mentioned items was obtained in densities of 18 plants $\mathrm{m}^{2}$ with hand weeding.

In sweet basil (Ocimum basilicum L.), the highest yield of linalool (63.88\%) and consequently of the oxygenated monoterpenes $(75.05 \%)$, was achieved in the weeding treatments (Sarrou et al., 2016). Vouzounis et al. (2003) reported that weed competition decreased the dry weight of lavender flowers by $52.4 \%$, while weeds control significantly increased the oil content from 5.82\% (weedy check) to $6.65 \%$. They added that the dry weight of leaves and flowers of transplanted oregano significantly decreased by $11.9 \%$ and oil content by $8.8 \%$ under

VI: The effects of S. hortensis densities and number of weeding times on density and dry weight of Amaranthus retroflexus and Solanum nigrum density

Density Number Density of A. retroflexus Dry weight of Density of S. nigrum Total density

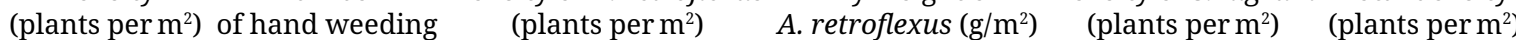

\begin{tabular}{|c|c|c|c|c|c|}
\hline \multirow{4}{*}{50} & Weedy check & $113.00 \pm 4.00^{\mathrm{a}}$ & $100.86 \pm 3.91^{\mathrm{a}}$ & $67.67 \pm 3.51^{\mathrm{a}}$ & $188.33 \pm 3.21^{a}$ \\
\hline & 2 times & $13.33 \pm 2.08^{\mathrm{d}}$ & $5.18 \pm 0.62^{c}$ & $3.00 \pm 00.00^{e}$ & $17.67 \pm 2.52^{\mathrm{e}}$ \\
\hline & 3 times & $9.67 \pm 2.08^{\operatorname{defg}}$ & $3.76 \pm 0.39^{\text {cd }}$ & $3.00 \pm 00.00^{e}$ & $14.00 \pm 2.00^{e f}$ \\
\hline & 4 times & $6.33 \pm 1.15^{\mathrm{gh}}$ & $2.60 \pm 0.48^{\mathrm{cd}}$ & $1.67 \pm 0.58^{e}$ & $9.00 \pm 1.73^{\mathrm{gh}}$ \\
\hline \multirow{4}{*}{75} & Weedy check & $110.00 \pm 2.64^{\mathrm{a}}$ & $100.39 \pm 1.20^{a}$ & $63.33 \pm 3.06^{b}$ & $180.33 \pm 3.06^{b}$ \\
\hline & 2 times & $11.33 \pm 0.58 \mathrm{def}$ & $3.89 \pm 0.18^{c d}$ & $3.00 \pm 1.00^{e}$ & $16.00 \pm 2.64^{\mathrm{e}}$ \\
\hline & 3 times & $5.33 \mathrm{~h}$ & $7.67 \pm 1.15^{\text {fgh }}$ & $3.13 \pm 0.08^{c d}$ & $14.23 \pm 0.29$ efg \\
\hline & 4 times & $7.33 \pm 1.15^{\mathrm{gh}}$ & $3.20 \pm 0.31^{\text {cd }}$ & $2.33 \pm 0.58^{e}$ & $10.67 \pm 1.53^{\mathrm{fgh}}$ \\
\hline \multirow{4}{*}{100} & Weedy check & $96.67 \pm 4.04^{b}$ & $83.53 \pm 2.15^{b}$ & $59.67 \pm 2.31^{c}$ & $162.00 \pm 5.57^{c}$ \\
\hline & 2 times & $9.00 \pm 1.00$ efgh & $3.27 \pm 0.26^{\mathrm{cd}}$ & $3.33 \pm 0.58^{e}$ & $13.33 \pm 1.15^{\mathrm{efg}}$ \\
\hline & 3 times & $7.00 \pm 1.00^{\mathrm{gh}}$ & $3.31 \pm 0.26^{\mathrm{cd}}$ & $2.00 \pm 1.00^{e}$ & $11.00 \pm 1.73^{\mathrm{fgh}}$ \\
\hline & 4 times & $8.00 \pm 1.00^{\mathrm{fgh}}$ & $2.76 \pm 0.58^{\mathrm{cd}}$ & $1.67 \pm 1.15^{\mathrm{e}}$ & $9.67 \pm 0.58^{\mathrm{fgh}}$ \\
\hline \multirow{4}{*}{125} & Weedy check & $91.33 \pm 5.51^{c}$ & $80.87 \pm 5.01^{b}$ & $54.67 \pm 2.08^{d}$ & $152.33 \pm 6.11^{\mathrm{d}}$ \\
\hline & 2 times & $12.33 \pm 1.53^{\mathrm{dxc}}$ & $4.04 \pm 0.46^{\mathrm{cd}}$ & $2.67 \pm 0.58^{e}$ & $16.00 \pm 1.73^{e}$ \\
\hline & 3 times & $7.00 \pm 1.00^{\mathrm{gh}}$ & $1.50 \pm 0.22^{\mathrm{d}}$ & $2.00 \pm 1.00^{e}$ & $10.00 \pm 1.73^{\mathrm{fgh}}$ \\
\hline & 4 times & $5.33 \pm 1.53^{\mathrm{h}}$ & $2.78 \pm 0.27^{\mathrm{cd}}$ & $1.33 \pm 0.58^{e}$ & $7.67 \pm 1.53^{h}$ \\
\hline \multicolumn{2}{|c|}{ LSD5\% } & 3.97 & 2.88 & 2.58 & 4.70 \\
\hline
\end{tabular}

Different letters in each column represent significance at 5\% probability level based on least significant difference (LSD) test 
weed competition, whereas the two characters were reduced by 43.0 and $28.0 \%$ in the transplanted sage.

The medicinal plant of $S$. hortensis is very sensitive due to low growth rate, height and canopy in the early stages of growth. Therefore, weeding weeds in the early stages of $S$. hortensis growth significantly prevents possible weeds damage, which the results are its evidence. Poor competition of medicinal plants with weeds depends on various factors such as lack of good canopies and root system, high needs for nutrients, weak resistance to severe environmental conditions, a prolonged flowering period, a tendency to scatter seeds; and a low harvest index (Mirshekari, 2013; Abaas, 2014; Carrubba and Militello, 2013; Ibrahim and Qasem, 2001).

The weeds of $A$. retroflex, $S$. nigrum and $C$. album were dominant weeds in the present study. The density and dry weight of the dominant weeds thus decreased with any increase in the density of $S$. hortensis. These findings are in agreement with previous study conducted by Ghahari et al., (2013), who reported that the effects of weeding time and plant density of fenugreek (Trigonella foenum-graecum) were highly significant on dry matter of weeds. Also any increase in plant density caused a significant decrease in weed dry weight. Barkhi et al. (2009) reported that dry weight of A. retroflexus decreased at the higher plant density of maize. Fayzbakhsh et al. (2007) also stated that dry weight of stem and leaf of maize decreased with any increasing density.

The lack of any significant effect of $S$. hortensis density on the dry weight of $C$. album and $S$. nigrum indicates that the increase in competition between plants at high densities has not been so enough as to reduce the weight of both dominant weeds. Also, the lack of a significant effect of weeding times on the dry weight of $C$. album compared to the weedy check probably indicates a delay in the emergence of this weed as indicated by field observations.

Basically, the changes in weed population density during the growing season can be attributed to the competition of adjacent plants such as weeds with weeds and weeds with S. nigrum, which causes a thinning, especially at higher densities. This finding is consistent with the results of Carrubba (2017), Gholamalipour Alamdari (2011), Gharanjic et al. (2013) and Dastorani et al. (2018).

Koocheki et al. (2005) reported that the decrease in the number of weeds over time is probably due to any increase in the weed inter and intraspecific competition over nutrition sources, light, etc. This competition will lead to the elimination of weaker plants. Therefore, more weeds in the weedy check treatment can be due to the longer period of weed interference and greater use of environmental potential.

\section{CONCLUSION}

The presence of weeds reduced the morphological and quality of active metabolites of $S$. hortensis. Also, the adequate density of $S$. hortensis is required due to the increase in the morphological, active metabolites and weeds control. As a result, weeds control in S. hortensis with weeding four times, i.e. 2, 4, 6 and 8 weeks after planting- WAP leads to a significant increase in dry weight, content and EO yield. However, delays in weed removal, such as twice weeding (4 and 8 WAP), significantly reduced measured traits. This indicates that weeding in S. hortensis due to low competitiveness should be done at the beginning of the growing period. Also, increasing the density of $S$. hortensis from 50 plants upwards provides proper relative control of weeds which in turn intensifies competition in plants and weeds, and hence increases the EO content due to stress conditions. Overall, due to the favorable effect of weed control under three or four weeding times on dry weight and content and EO yield of S. hortensis, weeding at the mentioned times is recommended in Gonbad Kavous area and areas with similar conditions to Gonbad Kavous.

\section{Acknowledgements}

The authors are thankful to the head of Department of Agriculture and Natural Resources College of Gonbad Kavous University for supplying necessary equipment to perform this experiment.

\section{REFERENCES}

ABAAS, I. S. 2014. Effect of biological competition of weeds on growth and volatile oil yield of marigold (Calendula officinalis L.) as medicinal plant used in herbal medicine of Iraq. International Journal of Pharmacy and Pharmaceutical Sciences, 6(1): 217-219.

ABOUZIENA, H. F. and HAGGAG WAFAA, M. 2016. Weed control in clean agriculture: a review. Planta Daninha, 34(2): 377-392.

AL-RAMAMNEH, E. A. D. M. 2009. Plant growth strategies of Thymus vulgaris L. in response to population density. Industrial Crops and Products, 30(3): 389-394. 
BARKHI, A., RASHED MOHASSEL, M. H., NASSIRI MAHALLATI, M., HOSSENI, S. M. and MOZZEN, S. 2009. Effect of planting pattern and plant density on growth, yield and yield components of maize (Zea mays L.) in competition with redroot pigweed (Amaranthus retrofelexus). Iranian Journal of Crop Sciences, 11(1): 67-81.

BOJOR, O. 2003. Guide of medicinal and aromatic plants from A to Z [in Romanian: Ghidul Plantelor Medicinale Şi Aromatice De La A la Z]. Fiat Lux: Bucharest, Romania.

CACERES, A. 2000. Calidad de la material prima para la elaboracion de productos fitofarma ceuticas. In: Primer Congreso International FITO 2000 Por la investigacion, conservacion y diffusion del conocimiento de las plantas medicinals. 27-30 de septiembre, Lima, Peru.

CARRUBBA, A. and MILITELLO, M. 2013. Nonchemical weeding of medicinal and aromatic plants. Agronomy for Sustainable Development, 33(3): 551-561.

CHAUHAN, B. S. and JOHNSON, D. E. 2011. Row spacing and weed control timing affect yield of aerobic rice. Field Crop Research, 121(2): 226-231.

CARRUBBA, A. 2017. Weed and weeding effects on medicinal herbs. In: Medicinal Plants and Environmental Challenges. Cham: Springer, pp. 295-327.

DASTORANI, M., GAHOLAMALIPOUR ALAMDARI, E., BIABANI, A., AVARSEJI, Z. and HABIBI, M. 2018. Study the several herbicides effect on weeds control and yield of cumin (Cuminum cyminum L.). Iranian Journal of Weed Science, 14(1): 83-95.

DREWS, S., NEUHOFF, D. and KÖPKE, U. 2009. Weed suppression ability of three winter wheat varieties at different row spacing under organic farming conditions. Weed Research, 49(5): 526-533.

FAYZBAKHSH, M. T., NEAMATI, N. A., MOKHTARPOUR, H., MOSSAVAT, A., SABERI, R. and SHEIKH, R. 2007. The effect of tiller removal and plant density on yield and yield component of sweet corn [in Persian with English Abstract]. Pajouhesh and Sazandegi, 77: 125-130.

GHAHARI, M., BARADARAN, R. and FORUTANI, R. 2013. Effects of planting density and weeding time on weeds and fenugreek dry mater. Middle-East Journal of Scientific Research, 18(8): 1171-1176.

GHARANJIC, A., GHOLAMALIPOUR ALAMDARI, E., BIABANI, A. and HAGHIGHI, A. H. 2013. Evaluating the allelopathic potential of (Polygonum convolvulus L.) on wheat (Triticum aestivum L.) [in Persian with English Abstract]. Journal of Applied Research of Plant Ecophysiology, 1(1): 83-95.

GHOLAMALIPOUR ALAMDARI, A. 2011. Preliminary phytoconstituents screening of some weeds and their potential toxicity on rice variety-Tarom via decomposition bioassay. In: International Conference on Environmental, Biomedical and Biotechnology. Vol. 16. Singapoore: IACSIT Press, 30-34.

GITI, S., DANESHIAN, J., SHIRANI RAD, A. H. and KHANJANI, M. 2013. Cytogate used for weed management and its effect in controlling alfalfa Flower Eater [in Persian with English Abstract]. In: Proceedings of the Conference on Applied Research in Sciences and Engineering. Islamic Azad University of Qazvin.

IBRAHIM, S. A. and QASEM, J. R. 2001. Weed competition in marjoram (Origanum syriacum L.). Dirasat Journal of Agricultural Sciences, 28(3): 184-193.

KIZIL, S., ARSLAN, N. and KHAWAR, K. M. 2007. Effect of different sowing densities on some characteristics of Isatis tinctoria L. and Isatis constricta Davis and on the recovery of Indican. Acta Agronomica Hungarica, 55(2): 251-260.

KOOCHEKI, A., GHOLAMI, A., MAHDAVI DAMGHANI, A. M. and TABRIZI, L. 2005. Principles of organic agriculture. Ferdowsi University of Mashhad Press.

KUMAR, R., GHORAI, A. K., SINGH, A. and KUNDU, D. K. 2015. The critical period for weed competition in relation to fiber yield of jute (Corchorus olitorius L.). Journal of AgriSearch, 2(3): 225-228.

MARTINOV, M., OZTEKIN, S. and MULLER, J. 2007. Drying: 85-97. In: OZTEKIN, S. and MARTINOV, M. (Eds.). Medicinal and Aromatic Crops. CRC Press.

MIRSHEKARI, B. 2013. Marigold (Calendula officinalis) yield as affected by lamb'squarters (Chenopodium album) competition. International Journal of Plant Production, 7(4): 659-664.

MOHAMMAD DUST CHAMANABAD, H. R. 2011. Scientific and practical introduction to the basics of weed control. Press Organization.

NAGHDI BADI, H., YAZDANI, D., MOHAMMAD ALI, S. and NAZARI, F. 2004. Effects of spacing and harvesting time on herbage yield and quality/quantity of oil in thyme (Thymus vulgaris L.). Industrial Crops and Products, 19(3): 231-236.

OLIVOTO, T., NARDINO, M., CARVALHO, I. R., FOLLMANN, D. N., SZARESKI, V., FERRARI, M. and DE SOUZA, V. Q. 2017. Plant secondary metabolites and its dynamical systems of induction in response to environmental factors: a review. African journal of agricultural research, 12(2): 71-84.

POURHEIDAR GHAFARBI, S. and HASSENNSZHAD, S. 2013. Identification and study of weeds population index of Shabstar fields. Journal of Agricultural Science and Sustainable, 3(23): 71-87.

RAOUFI, M., KHANJANI, M., DANESHIAN, J. and GITI, S. 2014. Integrated weed management in perennial Alfalfa and theirs effects on soil's micro fauna. International Journal of Farming and Allied Sciences, 3: 340-435. 
RAOUFI, M. and GITI, S. 2015. The effect of hand weeding and planting density on the yield, essential oil content and some morphological properties of peppermint (Mentha piperita L.) in Hamadan. Journal Crop and Weed, 11(2): 154-160.

SAFDAR, M., TANVEER, A., KHALIQ, A. and MAQBOOL, R. 2016. Critical competition period of parthenium weed (Parthenium hysterophorus L.) in maize. Crop Protestation, 80: 101-107.

SARROU, E., CHATZOPOULOU, P., KOUTSOS, T. V. and KATSIOTIS, S. 2016. Herbage yield and essential oil composition of sweet basil (Ocimum basilicum L.) under the influence of different mulching materials and fertilizers. Journal of Medicinal Plants Studies, 4(1): 111-117.

SAS INSTITUTE. 2011. Statistical Analysis Software/Stat Software, Version 9.3. $2^{\text {nd }}$ Edition. Cary, North Carolina, USA: SAS Institute.

SWANTON, C., NKOA, R. and BLACKSHAW, R. 2015. Experimental methods for crop-weed competition studies. Journal of Weed Science, 63(SP1): 2-11.

TURSUN, N., DATTA, A., TUNCEL, E., KANTARCI, Z. and KNEZEVIC, S. 2015. Nitrogen application influenced the critical period for weed control in cotton. Crop Protection, 74: 85-91.

TURSUN, N., DATTA, A., SAMI SAKINMAZ, M., KANTARCI, Z., KNEZEVIC, S. and SINGH CHAUHAN, B. 2016. The critical period for weed control in three corn (Zea mays L.) types. Crop Protection, 90: 59-65.

VOUZOUNIS, N. A., DARARAS, V. E. and GEORGHIOU, G. 2003. Chemical control of weeds in the aromatic crops lavender, oregano and sage. Technical bulletin No. 218. Nicosia, Cyprus: Agricultural Research Institute.

YADAV, T., CHOPRA, N. K., KUMAR, R. and SONI, P. G. 2018. Assessment of critical period of crop-weed competition in forage cowpea (Vigna unguiculata) and its effect on seed yield and quality. Indian Journal of Agronomy, 63(1): 124-127.

Contact information

Ebrahim Gholamalipour Alamdari: eg.alamdari@gonbad.ac.ir (corresponding author) Abdolmalek Karimi: ebrahim_19730@yahoo.com

Zinab Avarseji: avarseji@gonbad.ac.ir Ali Nakhzari Moghaddam: a_nakhzari@yahoo.com 